\title{
The Spin-off Chain
}

\author{
Samara Elpida', Kostas Galanakis², loannis Bakouros 3 , Spiros Platias ${ }^{4}$
}

\begin{abstract}
Several theories have been developed over a large number of years on the effort of localisation and exploitation of research results that take place in research laboratories and which can lead to the production of innovative products. This process is being facilitated by spin-off companies. The objectives of this paper is to review relevant models and build a conceptual framework - the 'Spin-off Chain' - to direct a undeveloped, region throughout the spin-off process. Unlikely to other models that consider the entrepreneurial-economic growth connection as shelf evident, the Spin-Off Chain integrates the regional and national context into the main university-based entrepreneurial process at a point that this connection is in its infantry and still requires top-down direction. Therefore, a pilot project is designed to apply the concept at the West Macedonia, Greece, aiming to generate the first spin-off company bypassing the barriers and shortages of the region.
\end{abstract}

Key words: entrepreneurship spin-off; national growth; technology transfer.

\footnotetext{
' University of West Macedonia. Department of Mechanical Engineering. Mater Lab. Kozani, 50100, Greece.

Tel: +30 24630-24846, Fax: +30 24630-55631. Email: esamara@uowm.gr

${ }^{2}$ Nottingham Business School. Nottingham Trent University. Burton Street, NGI 4BU, UK.

Tel: +44 (0) II 58488690 . Email: kostas.galanakis@ntu.ac.uk

${ }^{3}$ University of West Macedonia. Department of Mechanical Engineering. Mater Lab. Kozani, 50 I00, Greece.

Tel: +30 246I0-56660, Fax: +30 246I0-5666I. Email : ylb@uowm.gr

${ }^{4}$ TEI West Macedonia. Geotechnology and Environmental Engineering Department. Mater Lab. Kozani, 50100, Greece.

Tel: +30 246 10-40161, Fax: +30 24610-40161. Email: splatias@yahoo.gr
} 


\section{Introduction}

Entrepreneurship has been identified for decades as a major factor for economic growth, economic activity diversification and social cohesion (see for example: Rogers, 1986a, 1986b; Gartner, 1988). Moreover entrepreneurship has been recognized as a key instrument of technology innovation (European Commission, 1998, 2000). This recognition was an important change in Europe, where academic institutions have traditionally considered technology transfer and commercialization being outside their mission (OwensSmith et al., 2002) and entrepreneurial culture is not as developed as in the United States (OECD, 1999). Low and MacMillan (1998) defined entrepreneurship as "the creation of a new enterprise". In Gilsing, Burg and Romme (2010), technology entrepreneurship implies "the creation of new companies that exploit opportunities provided by technological innovation". Moreover, definitions of entrepreneurship often include the individuals, the opportunity, the context and the process over time (Gartner, 1985; Stevenson and Jarillo, 1990).

Entrepreneurship is defined for this paper as the process that leads to the emergence and development of new ventures based on the exploitation of new or existing knowledge. As this knowledge needs to be transferred from a knowledge creation institution, university spin-offs are considered as one major source of entrepreneurial activity (Rasmussen et al., 2006). For many researchers, furthermore, spin-offs are considered as just a special case of technology transfer (Mowery and Shane, 2002; Pérez and Sánchez, 2003; Samsom and Gurdon, 1993). Landry et al. (2006) recognised that spin-offs are the most visible commercial outcome of university research and Bathelt et al. (2010) acknowledge that the creation of spin-offs can be a significant mechanism to generate and sustain regional economic growth and competitiveness. Following a comprehensive survey Pirnay et al. (2003) defined spin-offs as "new firms created to exploit commercially some knowledge, technology, or research results developed within a university".

University spin-offs face initial lack of resources and may have to overcome substantial barriers of entry to markets, or establishing the proper value chains (Glader, 2004). Furthermore, they often lack marketing, selling and/or managerial skills (Geenhuizen and Soetanto, 2009).
Universities as context for entrepreneurship usually operate under the rules of the public sector, which frequently are more rigid and require different levels of involvement by actors with priorities other than the knowledge commercialisation (Mustar et al. 2006). In general however, factors like infrastructure or access to capital might be more important for a successful commercialization process than the research outcomes themselves (Temple, 1996).

It is evident however that some universities are more likely than others to reinforce entrepreneurial activity and to adopt policies designed to support creation of spin-offs, e.g. exclusive licenses, taking equity, creating pre-seed stage capital etc. (Landry et al., 2006). During the years, several models have been developed and tried to communicate to academics, policy makers and managers how entrepreneurial spin-offs occur and which factors affect the outcome of this process. Some of them however, are static providing only a snapshot of the processes and interactions between the stakeholders that lead to spin-off formation (Bathelt et al., 2010). The objectives of this paper is to review relevant models and build a conceptual framework - the 'Spin-off Chain' - to direct a undeveloped, regarding entrepreneurship, region throughout the spin-off process. Unlikely to other models that consider the entrepreneurial-economic growth connection as shelf evident, the new concept integrates the regional and national context into the main university-based entrepreneurial process at a point that this connection is in its infantry and still requires topdown direction. The aim is to assist the different stakeholders of such a region - the West Macedonia, Greece - to generate spin-off companies under a pilot project bypassing the barriers and shortages of the region.

On the next sections models of the spin-off process that have been developed over time are presented and the conceptual framework concept is built. Its implementation at a specific case, the Region of West Macedonia is presented on section 3. The discussion and conclusions close this paper.

\section{Theories about the Spin-Off Process}

Rasmussen (2006) models the process of a university spinoff (Fig. I) simply as the process where a research-based 
idea or opportunity, one person or a team of entrepreneurs, and the relevant context create the necessary properties for a new organization to emerge (Rasmussen, 2006).

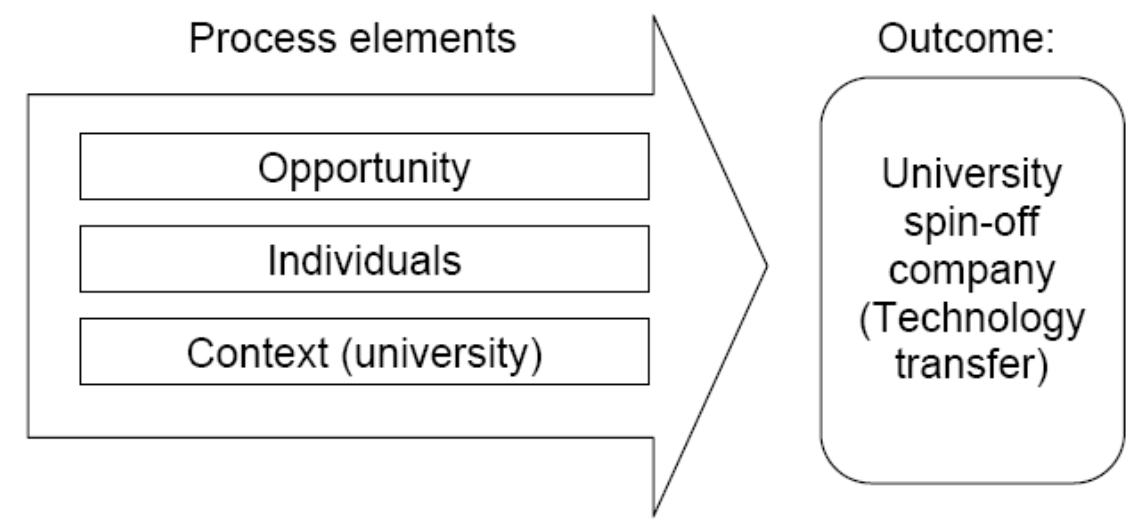

Figure I. The entrepreneurial process of university spin-off creation (Source: Rasmussen, 2006).

According to Ndonzuau and his colleagues (2002) the process of a spin-off development from the standpoint of both public and academic authorities is comprised of four stages and very similar to the 'stage-gate' process (Cooper, 1993) described for the new product introduction process. "Each of these stages has a specific function in the global spin-off process. The first stage generates and assesses ideas with regard to possible commercialisation; the second stage considers these ideas and translates the most promising of them into final entrepreneurial concepts; the third stage realises the best concepts by launching new spin-off firms; and the fourth stage consolidates and strengthens the economic value created by these new firms" (Ndonzuau et al. 2002:282). A note of caution must be made with respect to the model's suggested assumption of linearity (Fig 2). The four stages are not wholly independent of each other.

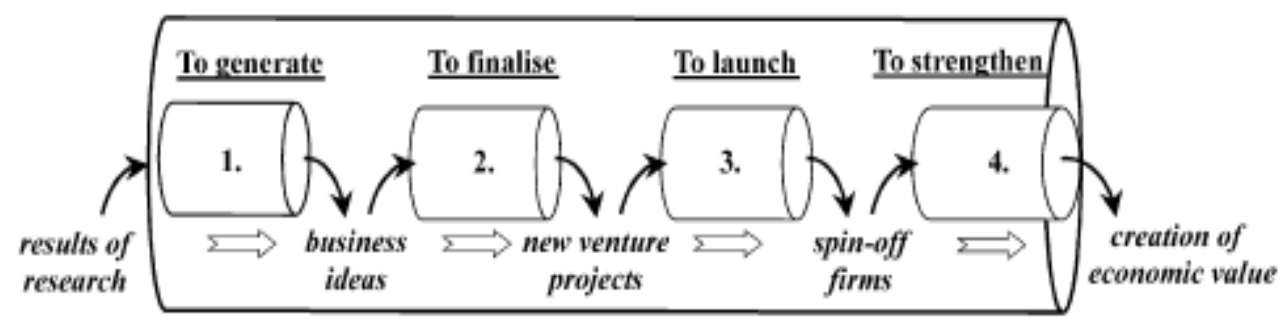

Figure 2. The global process of valorisation by spin-off (Source: F.N. Ndonzuau et al. 2002, pp 28I-289).

The programme IDEAS with the Universidad Politecnica (2002) de Valencia (UPV) promoted a process able to spinoff and start-up new companies out of the university activity using the metaphor of a new conceived and born person. On this model, the spin-off generation process (Fig. 3) can be seen as a chaotic process driven by the interaction of three elements: the entrepreneurs (E), the opportunity $(O)$ and the resources $(R)$. These three elements at the first awareness or 'embryo' stage need to be combined by the entrepreneur's mind to create the fertile seeds of new ideas. These seeds are accumulated to a pre-incubator phase to concrete 
concepts, configuring the Cells of Opportunities ( $\mathrm{CoO}$ ). The 'healthiest', which has a balance between the availability of entrepreneurs, opportunities and resources born to a distinctive form, which however needs an incubation period to gain all the characteristics necessary to succeed in a globalised environment.

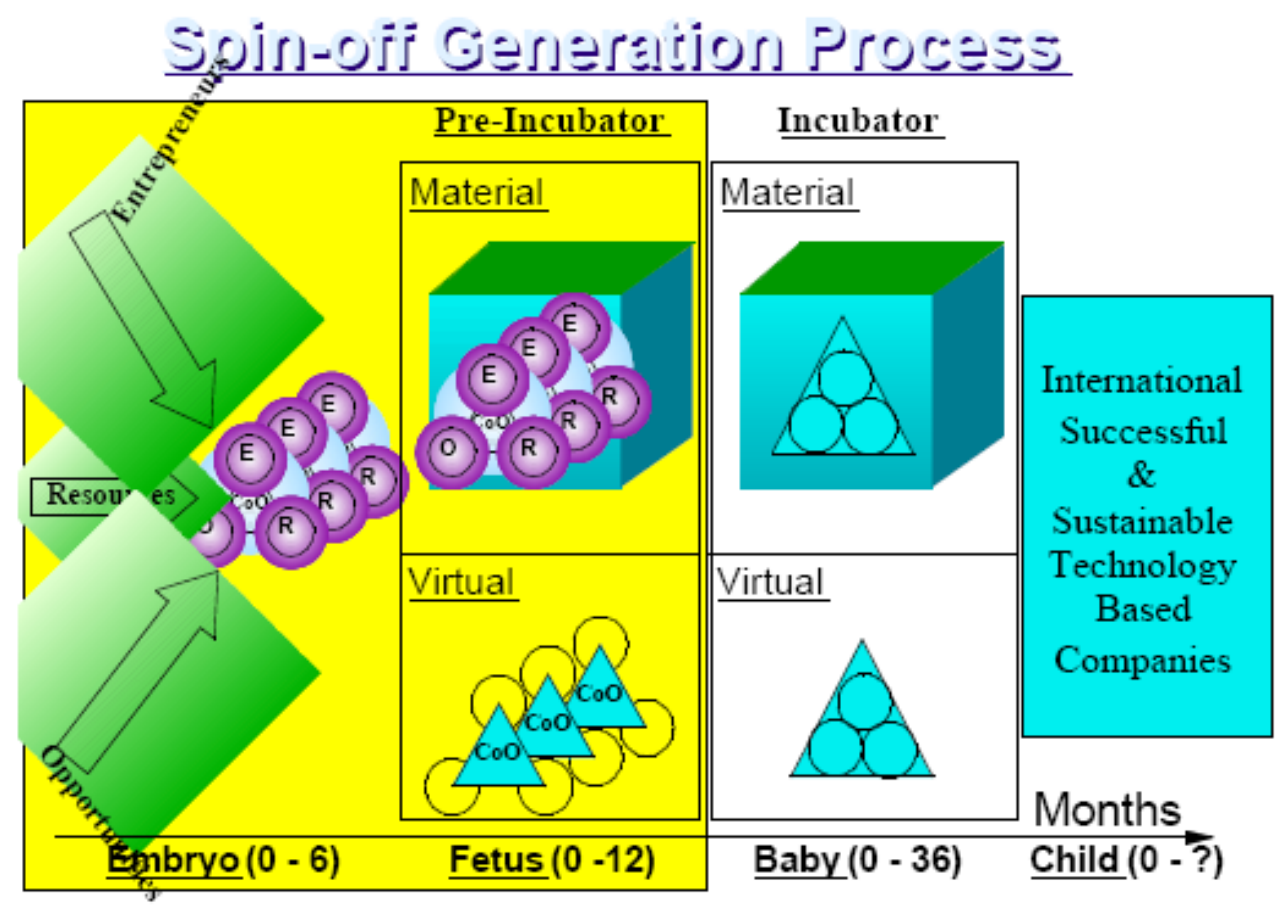

Figure 3. Sequence of the spin-off generation process at UPV (Source: USINE project, http://www.usine.uni-bonn.de)

\section{I The Core Entrepreneurial Action}

Studying the major issues involved in the transformation of knowledge into the creation of economic value through product commercialization and employing a dynamic perspective as suggested by Bathelt et al. (2010), four basic stages identified as the "Core Entrepreneurial Action". The first stage explores ideas of products and services and the mechanisms and criteria used for selecting them to be developed. The second stage realises the business concept of the idea which is the stage where a firm is designed. The basic aim is to the imprint of the processes and functions, defining and distributing the required human and economic resources that are judged necessary for the creation of cash-flow for the growth and survival of the company. The third stage deals with finding the financial resources to develop the business concept. The fourth stage 'runs' in parallel to all the others, consolidating and strengthening an entrepreneurial culture necessary for fertilising the ideas and concepts to this direction:

- Idea is considered as the beginning of the spin-off process. It includes activities that proceed concept's generation and often is unstructured, i.e. constant researching, for identifying the stimuli leading to a possible change. Implementing an idea is an extremely risky decision, especially when this comes as a result of basic scientific/technological research. For this reason, a certain selection process is of great importance, although often at this stage selection is based on a person's irrational conviction to success. Especially between researchers that have used to work in decentralised and individualistic environments, mistrusting external actors to investigate their results (Mintzberg, 1989). To transform this process to a structured one, abilities and the skills to identify and evaluate the most promising ideas must be developed and above all mutual trust and 
efficient internal exchange of information (Ndonzuau et al., 2002). This means that when this phase is completed the researchers will have already made up their minds regarding which idea is worth implementing (Etzkowitz et al., 1998). One of the most important tasks is to persuade 'gate keepers', e.g. directors of research centres and companies, to keep their doors open in order to allow promising ideas to be detected.

In order to commercially exploit any ideas, an analysis of their technological, commercial and personal aspects is required (Ndonzuau et al., 2002). According to Cooper (1993) screening of ideas is characterized as a "gentle" one, because often the selection is based on the subjective opinions of the persons that proposed the ideas on the first place. Therefore, we suggest that these criteria may include 'soft' judgement, for example: the level of maturity, the level of excitement, the level of visible outcomes.

- Business Concept. Feasibility of the concepts needs to be judged against technical, scientific, market promise, production capabilities and its potential to be protected against competition. Shortage of capabilities that have not been considered will become apparent during the development or the production phases where capital and resources have been spent and wasted (Oakey, 1995; Reitan, 1997). In this paper the authors suggest three categories of business concept criteria:

o Technology/Scientific research. Technological/ Scientific evaluation requires the ability to assess the extent to which research results are stable and sufficiently developed to lead to industrial exploitation by identifying their possible applications, assessing their technical feasibility, consistent and economical production and, in some circumstances, suggesting further research and development. This task requires the development of expertise within the organisation (i.e. other researchers) or external partners (i.e. supply chain, supportive firms). However, this evaluation is necessary but not sufficient to validate the potential concept in the market (Rasmussen, 2006).

o Market research. From the perspective of business exploitation, the commercial potential must also be assessed to verify the extent to which there might be a viable market. At this stage multiple questions must be addressed: Who are the key players in those markets? How high are the barriers of entry? Is the potential good enough to build up a viable business? (Timmons, 1994). At this stage universities are required to develop structures to help researches to identify the market needs and bring them in networks that could exploit them (van Burg et al., 2008).

o Protection potential. This criterion has to do with the potential of any concept to be protected. For example the possibility to apply for a patent is used as such indicator (Landry et al., 2006). Three are the criteria that an invention should have in order to achieve a patent: to be new, not to be obvious and to be useful (Rappert et al., 1999). However, patenting is not the only way of protection. Often the ability of a firm to develop, improve and generate new products/services faster than anybody else can be more effective, generating higher barriers to competitors (Stalk and Hout, 1990). As far as the entrepreneurial spin-offs are concerned patenting or licensing is probably the best way to protect an idea which helps on when the new venture request finance from investors. However it requires a well-functioning market for technical knowledge and a legal system to protect intellectual property (Shane, 2004).

Regarding university spin-offs a second issue in the protection potential area is to identify the owner of the results on which an idea is based (Ndonzuau et al., 2002). We suggest, following van Burg et al. (2008) that research organisations need a clear policy which will aspire and give incentives to their researchers to come forward with their ideas. Furthermore, they need to create strong legal partnerships, in the case of collaborative research projects between research groups and funding organisations (public or private), that will give full description of ownership, rather than supporting loose agreements.

While an idea has been protected then it can be presented outside its original "birthplace". Moreover, milestones from development to product/service launch and timelines for these 
actions will be identified. A business plan could describes the resources, people, money and equipment that are necessary for each action and identifies the ability of the firm or university to undertake it successfully in the specified time. Finally, it gives a concrete and practical guideline to entrepreneurs to defend their idea and describe their exploitation against potential investors (Sahlman, 1997).

- Attracting financial sources - own resources of the entrepreneur, university, public funding, or external investment, e.g. venture capitalists, business angels, investment banks (Oakey, 1995; Reitan, 1997) - may be the only factor that separates a successful business concept from a wasted idea (Rasmussen and Borch 2010). The financial contribution requires a concrete agreement illustrating responsibilities and adaptability to business needs. Universities and research organisations need to prepare and train their researchers to such skills and bring investors close to them (van Burg et al., 2008).

- Entrepreneurial culture. The whole effort may be supported or worn out if the appropriate culture is not present. Any idea, technological advance, innovation or economic growth created by an organization is dependent on how that organization's culture and environment fosters or inhibits these developments. Several factors, such as government policies and the regulatory framework, may influence or built the necessary levels of business culture (Sahlman, 1997). However, the most important cultural element is whether researchers have a strong direction towards entrepreneurship, or the idea has been 'cultivated' by their host organisation as an alternative path of personal and professional success. Druihe and Garnsey (2002) examined university spin-out cases, finding that motivation, experience and knowledge of the entrepreneurs can overcome difficulties like identifying productive opportunities and obtaining the resources for the necessary productive base. Hence, it is important to understand the underlying motivation of the inventors to take the decision to start up a business. The explanations can be classified into two main groups: psychological and career-oriented explanations. Psychological explanations are based on the strong interest of inventors to be involved in the further development of the technology and to bring it personally into practice. Career-oriented explanations refer to the desire of inventors to make money and to stay independent. Additionally, researchers who have achieved a higher rank within the university are more likely to start up companies than others; the same is valid for researchers with a higher level of prior entrepreneurial experience (Shane, 2004).

\subsection{The Supportive Structure and Environment}

The basic Entrepreneurial Process alone may be flourishing; however, the result will face a higher or lower risk of success if certain environmental elements and supportive structures are not present. On one hand the Operational Environment: market needs, human capital, appropriate government policies and appropriate regulatory framework. On the other hand, supportive structures of the early stages: financial institutions keeping positive cash flow throughout the early stages; and, bridging organisations to incubate the early days of the new spin-off in a relatively favourable environment. All these different elements must work together in order to support and progress the spin-off company to a maturity stage:

- Market Needs. A critical factor for sustainable success of the spin-off is to connect the new concept with adequate market needs. Different studies found that pull factors, such as market opportunities, motivate the creation of university spin-offs (Smilor, Gibson et al. 1990; Chiesa and Piccaluga 2000). Additionally, studies on University-Industry relations shows that universities with closer ties to industry tend to generate greater numbers of spin-offs and exhibit more entrepreneurial activity (Cohen et al., 1998; Roberts and Malone, 1996). The business concept has to be balanced according to the market needs or to identify new paths, developing a new market segment. Hence, the relationships between the university, business people and possible users of the new concept are crucial for the new venture in order to identify opportunities and limitations. This relationship however needs to be developed and offered as a professional service by the university to its members.

- Human capital plays crucial role in the context of spin-off development. Skills and experiences of the entrepreneurial inventors are likely to be critical for a successful commercialization, although they may need to team up with other people to develop a complete set of 
management skills (Bathelt, H., Kogler, D.F., Munro, A.K., 2010).

- Government Policies. The contribution of university generated knowledge to economic development and growth in technological advanced economies has increased dramatically during the last decades (OECD, 2003). This has made policy makers interested in the role of universities as potential vehicles for innovation and job creation. Since the early 1990s many mechanisms aiming to promote the creation of technology-based firms have been set up in most industrialized countries (Storey and Tether, 1998). New initiatives and supporting organizations like incubators, technology transfer offices, commercialization units and entrepreneurship centres were created to play a role in university spin-off development. Especially, in the initial phase of the creation of university spin-off companies, a range of public interventions are being required starting from incubators and ending-up to seed and venture capital existence. Furthermore, a clear policy for directing public research and its outcomes to the direction of commercialisation is necessary. For example, such a policy could connect university public financing or evaluation criteria to entrepreneurial related results.

- Regulatory Framework. Regulations influencing the spin-off creation may be set at local, regional, national or even global level. Coherence and complementarities between different levels is clearly essential. In 2003 the European Council (E.C. 2003) guidelines recommended fostering entrepreneurship through the tax and regulatory environment for new businesses, insolvency law reforms and promoting efficient financial markets in all member states.

- Sources of capital. Finance is pivotal for any enterprise but, for a spin-off company can often be the critical difference in whether an idea is turned into a new product, service or technology or not. Finance, which one may think is the less problematic of factors for a person with a great idea or invention, can, at the end; turn out to be the most critical factor. The last twenty years a dramatic rise has occurred in the availability of venture capital and business angels financing (Gompers and Lerner 1999), providing an attractive source of external financing. The main gap in the provision of spinoff finance is just after the seed capital stage creating what is known as the "death valley" (Gompers and Lerner 1999). More particularly, while grant aid from public authorities is often available for proof of concept and related research activities, it is much more difficult to finance the next stage when commercial development starts but the company has not yet begun to generate sufficient revenue for its costs. Business Angels are an important potential source of capital funding at this stage filling the gap. Sometimes the reluctance of business angels to invest in research-based projects is that these people come from a background that lack personal knowledge of the technologies typically involved in university spin-offs. The early stage funding gap can be addressed in different ways. For example, by provision of government grants and public incentives for creating regional or sectoral venture capital funds (Reitan, 1997).

- Bridging Institutions. Bridging institutions, such as technological parks, incubators, innovation centres, act as intermediaries between companies and the performers of research. They are created in order to develop and encourage the process of diffusion and transfer of knowledge and technology. In general, their economic, organisational and administrative missions are assigned by policy making bodies and their role is to span the gap between the different stakeholders involved in different levels, at the complex process of the university spin-off (Mustar et al., 2006). According to the European Commission (2000) academic spin-off companies which are created in regions outside established high tech clusters tend to stay small and normally they fail to grow and to become global leaders in their sector.

All these stages and factors play a significant role in the process of a spin-off development creating a systemic framework that we name the "Spin-off Chain" (Fig. 4). 


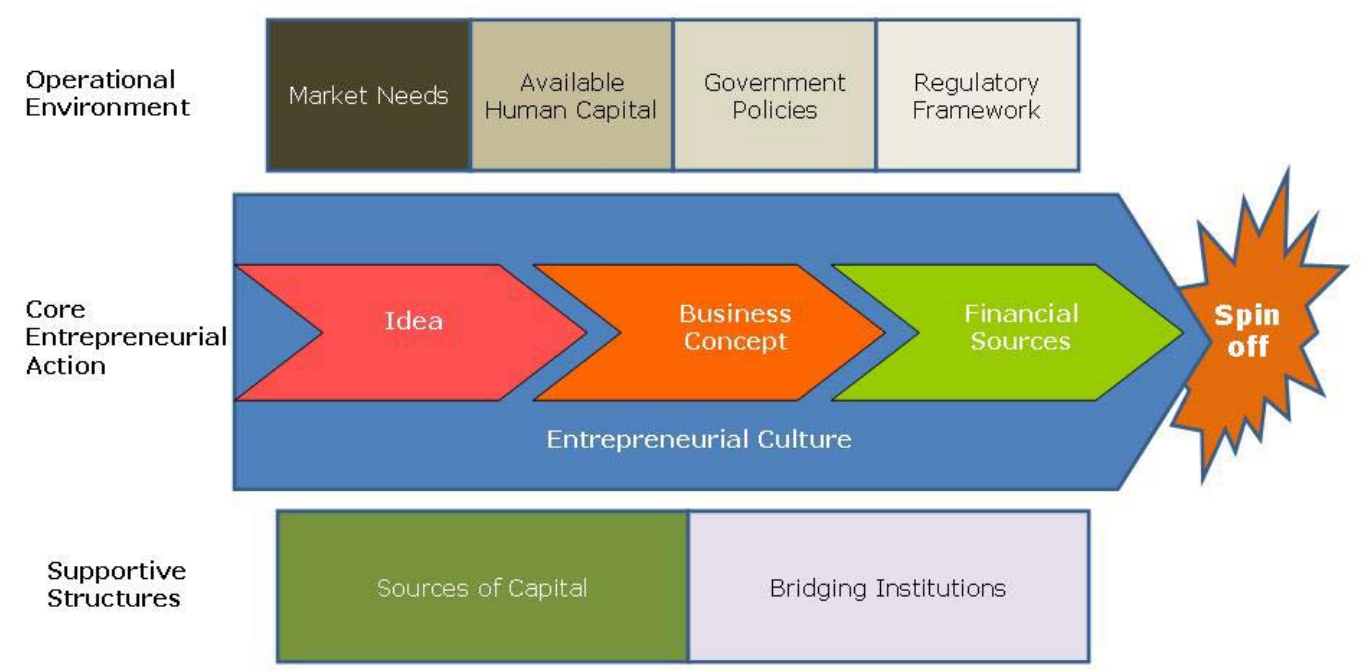

Figure 4. The "Spin-off Chain” (Writers own illustration)

\section{Appling the "Spin-off Chain" Concept in a Greek Region}

The authors conducted a case study based on the "Spin-off Chain" concept in one Greek region, the Region of West Macedonia ${ }^{5}$. The case study describes the capacity level of the region to develop university spin-off companies, following the development path of a new spin-off company that established in 20096. The concept used to communicate and enhance entrepreneurial culture between the academics and researchers, raising awareness of available services and helping these services to

5 The case study conducted under the frame of the "SMART II (Sustainable management and action to promote regional transition)" program and the action "OFFINNO+ / Offensive Innovation Plus", where the objective of the program was the creation of spin-off companies for further promotion of innovative products and services in the domestic and international market. The project involved extensive interviews with the region's stakeholders, supportive training relating to entrepreneurship and dissemination activities to foster entrepreneurial culture.

6 "SUSTAINABLE TECHNOLOGIES ON ALTERNATIVE \& RENEWABLE FUELS" "STAR FUELS" S.A. Some basic data from the business are:

- The proposed enterprising idea lies in the completed and sustainable energy exploitation of biogas, to completely cover the needs of electric energy and heat of stock farm units.

- The newness based on the use of fuel cells instead of conventional generator.

- $\quad$ First business capital necessary: 90.000 Euro.

- A venture capitalist participated to the company with a capital of $240.000 €$. understand the spin-off process in order to exploit the research results of researchers in the region. Furthermore, it illustrated the limitations in the region and the areas that need to be developed further to increase the capacity of the region to support spin-off activity.

\section{I. Basic Entrepreneurial Process: The Capacity of West Macedonia}

The Region of West Macedonia is situated in the NorthWest part of Greece, bordering with the Greek Regions of Central Macedonia (East), Thessaly (South), Epirus (West). On the North forms the Greek border with the regions of Bitola (F.Y.R.O.M.) and Korce (Albania).

The region's economy is based heavily on the secondary sector (Table I) due to the mining activities, the production of electric power (70\% of country's total power is produced in the Region) and the fur-leather sector. Primary sector underperforms significantly on productivity, although lately have developed new directions on niche markets (e.g. organic production, high end wine production). Tertiary sector, although underperforms comparing to secondary, develops important areas of activities especially around tourism sector and supporting services to the main manufacturing activities. Overall though the unemployment rate in the region is $12.5 \%$, one of the highest among the Greek Regions. This

\footnotetext{
${ }^{7}$ Eurostat, data for 2008
} 
demonstrates the rigidity of the workforce and the general low level of entrepreneurial culture as young persons base their future employment heavily to the Public Electric Company and its related activities.

During the last few years however the raise of awareness in relation to environmental concerns has diffused a
'Green Entrepreneurial' culture. Originally this direction has been led by the impacts in the Region by the energy and fur related production activities. This culture is directing all new economic activities toward sustainable development in agriculture and tourism.

\begin{tabular}{|l|c|c|}
\hline & Regional GDP & Employment \\
\hline Primary sector & $13.4 \%$ & $23.5 \%$ \\
\hline Secondary sector & $47.5 \%$ & $32.9 \%$ \\
\hline Tertiary sector & $39.1 \%$ & $43.6 \%$ \\
\hline
\end{tabular}

Table I. West Macedonia GDP and Employment by sector of activity (Source: General Secretary of Research and Technology)

\begin{tabular}{|l|c|c|c|c|}
\hline & 2005 & 2006 & 2007 & 2008 \\
\hline General unemployment rate & $18 \%$ & $14,2 \%$ & $12,1 \%$ & $12,5 \%$ \\
\hline $\begin{array}{l}\text { Young unemployment rates (between I5 and } \\
24 \text { years) }\end{array}$ & $44,1 \%$ & - & - & $36,8 \%$ \\
\hline Female unemployment rates & $28 \%$ & $20,3 \%$ & $18,4 \%$ & $19,3 \%$ \\
\hline
\end{tabular}

Table 2. West Macedonia unemployment rates (Source: Eurostat)

\begin{tabular}{|c|c|c|c|}
\hline Institution & $\begin{array}{c}\text { Year of } \\
\text { establishment }\end{array}$ & Departments/Main activities & Comments/Achievements \\
\hline $\begin{array}{l}\text { University of West } \\
\text { Macedonia } \\
\text { (U.o.W.M.) }\end{array}$ & 2004 & $\begin{array}{l}\text { a) Faculty of Education } \\
\text { i) Elementary Education } \\
\text { ii) Nursery Education } \\
\text { b) Faculty of Engineering } \\
\text { i) Mechanical Engineering } \\
\text { ii) Engineering Informatics \& } \\
\text { Telecommunications }\end{array}$ & $\begin{array}{l}\text { The Department of Mechanical } \\
\text { Engineering was already operational as } \\
\text { part of Aristotle's University of } \\
\text { Thessalonica (A.U.Th.), the larger } \\
\text { University in Northern Greece and one } \\
\text { of the major Universities in Greece. } \\
\text { Through this connection the members } \\
\text { of staff have long and high level of } \\
\text { experience in research, innovation } \\
\text { strategies and knowledge management. } \\
\text { The U.o.W.M. is strongly linked to the }\end{array}$ \\
\hline
\end{tabular}




\begin{tabular}{|c|c|c|c|}
\hline & & $\begin{array}{l}\text { c) Other Departments } \\
\text { i) Balkan Studies } \\
\text { ii) Applied and Visual Arts }\end{array}$ & $\begin{array}{l}\text { University of Thessaly, with long } \\
\text { experience in managing RIS projects. }\end{array}$ \\
\hline $\begin{array}{l}\text { Technological } \\
\text { Education Institute } \\
\text { (T.E.I.) of West } \\
\text { Macedonia }\end{array}$ & 1983 & $\begin{array}{l}\text { a) The Applied Technology } \\
\text { Department (Mechanical, } \\
\text { Electrical, Industrial Design, } \\
\text { Geotechnology and Environment } \\
\text { Antipollution Department and } \\
\text { the General Department); } \\
\text { b) Management and Economics } \\
\text { (Logistics, Economics and } \\
\text { Business Management); } \\
\text { c) Agricultural Technology; } \\
\text { d) Health Services (Obstetrics) }\end{array}$ & $\begin{array}{l}\text { The mission statement underlines the } \\
\text { practical and applied side of its courses } \\
\text { and research undertaken, highlighting } \\
\text { the spin-off development opportunities } \\
\text { for the regional economy. } \\
\text { Applied research is carried out through } \\
\text { fifteen (15) projects of which the } \\
\text { majority are connected directly to } \\
\text { firms. The TEl of West Macedonia, in } \\
\text { part due to have been in existence for } \\
\text { relatively longer than the University, } \\
\text { and the applied nature of activities has } \\
\text { created stronger links with local and } \\
\text { national industries }\end{array}$ \\
\hline $\begin{array}{l}\text { the Institute of } \\
\text { Solid Fuels } \\
\text { Technologies and } \\
\text { Applications } \\
\text { (ISFTA) }\end{array}$ & 1987 & $\begin{array}{l}\text { ISFTA acts as consultant to the } \\
\text { Greek Government, the Public } \\
\text { Power Corporation (PPC), the } \\
\text { Institute of Geological and } \\
\text { Mineral Exploration (IGME) and } \\
\text { to any other company or } \\
\text { organization involved in the } \\
\text { energy sector and is actively } \\
\text { involved in the Governmental } \\
\text { planning for power production } \\
\text { and industrial development. }\end{array}$ & $\begin{array}{l}\text { ISFTA is the main Greek organisation } \\
\text { for the promotion of research and } \\
\text { technological development aiming at the } \\
\text { improved and integrated exploitation of } \\
\text { solid fuels and their by-products with } \\
\text { several research projects funded by } \\
\text { national and European frameworks. } \\
\text { In } 2005 \text {, ISFTA has been awarded the } \\
\text { title of Excellence in Research and } \\
\text { Technology. It ranked } 6^{\text {th }} \text { among more } \\
\text { than } 40 \text { Greek Research and } \\
\text { Technology Organisations supervised } \\
\text { by the General Secretary of Research } \\
\text { and Technology. }\end{array}$ \\
\hline
\end{tabular}

Table 3. Knowledge Capacity of the Region

The Green Culture has dominated the Ideas which are expressed $^{8}$ in our project by researchers from all the

8 Some of these ideas are: i) Technology of Hydrogen (production by mining and renewable fuels and use in fuel cells), ii) Energy exploitation of biomass (thermochemical (gasification and pyrolysis) and biological methods (anaerobic fermentation), iii) Biofuels, iv) Growth of antipollution technology (gas pollutants), v) Modelling energy and industrial systems, vi) Energy
Knowledge Institutions of the Region. These institutions - University of West Macedonia; Technological Education Institute (T.E.I.) of West Macedonia; the Institute of Solid Fuels Technologies and Applications (ISFTA) - are in general new establishments and in an extend their core activities still under development (Table 3). They have

saving, vii) Co-production of electricity and heating and iix) Abstraction of $\mathrm{CO} 2$ from activities of combustion. 
however sufficient capacity and facilities to transform the ideas to operational product concepts - or collaborate with neighbour institutions. Additionally, during the last 5 years all the researchers and students have followed entrepreneurship related training programmes, which however were driven centrally by Government's policies. This has enhanced the level of awareness to the importance of spin-offs, entrepreneurial activities and new business establishment related needs.

The Region however lacks, in general, experienced business mentors and coachers that could direct young researchers to develop viable business concepts on hightechnology or green related fields. Furthermore, the Financial Sources are based almost entirely outside the Region - mainly in Athens and Thessaloniki - which creates difficulties on visibility of those ideas and trust between the founders and the financing organisation. The main stakeholders have no direct financial capacity to support spin-offs. The high risk ventures finance sector however is underdeveloped in Greece, with weak level of record of activities, beside the strong public incentives during the last decade. The sector is based entirely to Venture Capitals subsidised by national grants and Bank loans. Initiatives by large firms to support such activities or Business Angels are practically negligible. In the case of our project and the STAR Fuels creation the basic finance (250.000€) came from a Venture Capital, acquiring 50\% of the shares?.

On the other hand, the related researchers in the Region demonstrated strong directions toward research with applied results. They are able to identify to what extend an idea is mature enough (technological and operational) and oriented to real needs and market gaps. It is not clear however that IPR consideration is wide spread.

Summarising the above analysis, the Core Entrepreneurial Action Capacity of West Macedonia has been outlined to the diagram in Figure 5. This shows that although the entrepreneurial culture is on an average level by Greek standards, it is lacking on the capacity to transform ideas to concrete business concepts and find adequate financial support. The ideas are strongly focused on the core activities of the region. However the dominant player, i.e. the public power corporation, could play a vital role to support and promote such activities.

\subsection{Supportive Structures and Environment: The Capacity of West Macedonia}

The Market Needs in the Region are dominated by the Public Power Corporation and energy related issues. Even the agricultural sector is observed to be restructured according to energy related trends i.e. with dynamic entry of the energy cultivations (cardoon, cane, sorghum, coleseed, etc.), that can be used for the production of liquids bio-fuel. However, during the last decade another pole of economic activity has emerged, tourism. With specialisation to winter tourism, natural conservation and 'active' holidays several areas of the Region have developed impressively.

On the other hand the emergence of the University and T.E.I. of West Macedonia has enhanced the quality of the available human capital and slowed the trend of braindrain. The University of West Macedonia in Kozani, is mainly manpowered by scientists, academics and engineers with long experience in the educational and research field, as well as in the entrepreneurial environment. However the majority of them are living at Thessaloniki ( 1.5 hours away), reducing the ability of the Region to develop a critical mass of highly skilled and inspiring human base.

Innovation, technology and entrepreneurial related policies are heavily controlled by the directions that are determined by the General Secretary of Research and Technology (GSRT). The GSRT coordinates the research programmes that are financed by the structural programs of the European Union, although they originally had designed to operate in local level. Most of the regional authorities in Greece however, didn't demonstrate strong capacity and knowledge availability, resulting to a de facto return of control to central government. Furthermore, the decision of creating several development agencies at each region broke the available resources and didn't help practically the real regional coordination of activities.

\footnotetext{
9 The rest of the finance came from public funds through the PRAXE framework, financed by the European Regional Development Funds (ERDF), www.gsrt.gr
} 


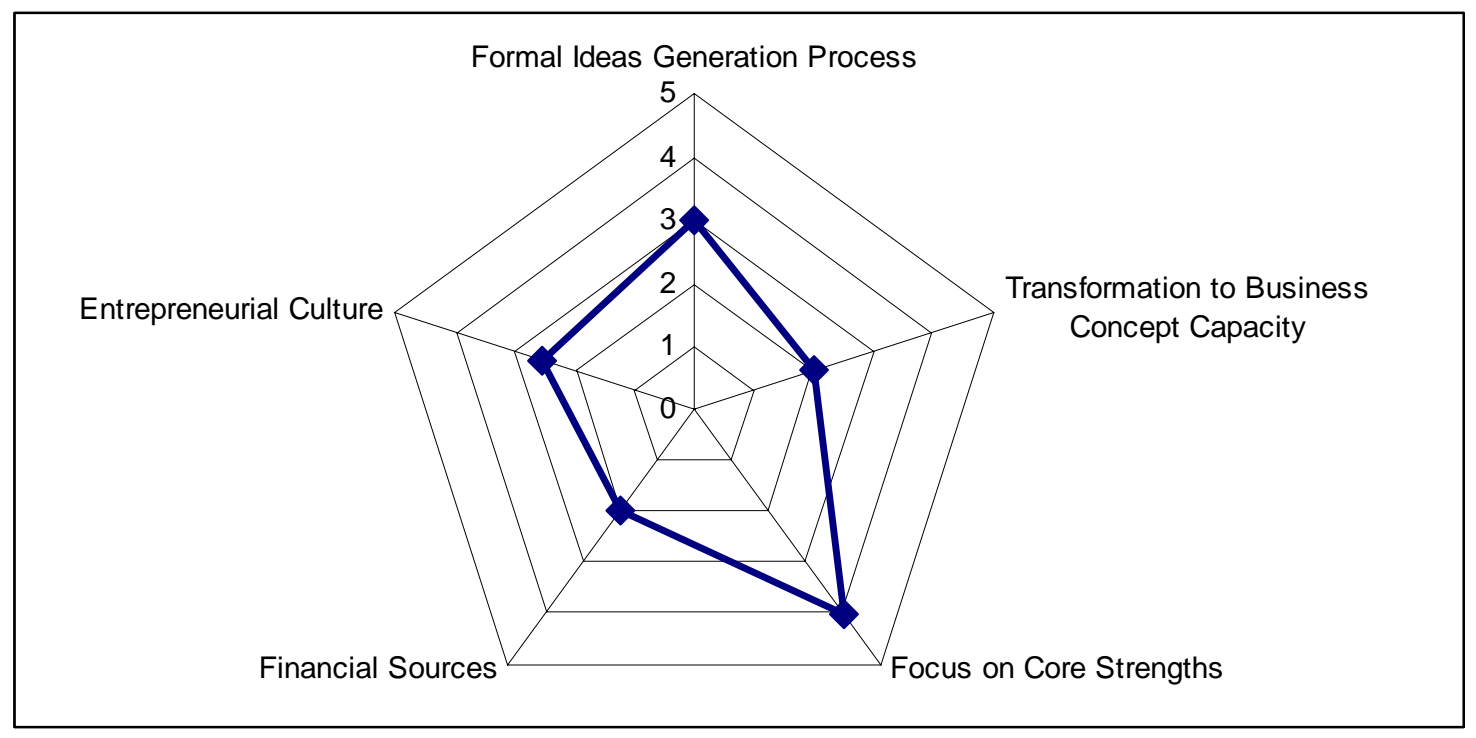

Figure 5. Core Entrepreneurial Action Capacity of West Macedonia

During the $3^{\text {rd }}$ Community Support Programme GSRT introduced a special action for the creation of spin-off companies called "PRAXE". This action had two phases: the first phase included investment preparation activities (seed capital) and the second one investment launching activities. More specifically the first phase was implemented through an open tender and supported the following activities:

- Creation of new products, methods and production procedures

- Construction and perfection of industrial standard, operating tests and demonstration

- Protection of intellectual property rights

- Drafting of business plans, marketing studies, financial plans

- Participation at exhibitions, contests and any promotion activity

- Use of experts in legal, economic and technical matters related to intellectual property rights

- Search for venture capitalists
To enter in the second phase, it was required that research entities documented the technical and commercial feasibility of the product or service, based on the business plan. In addition a private investor had been found. Expenditure for equipment, the purchase of a building, consultancy services and operating costs of the new venture were financed during the first three years of their development. Through the PRAXE action 200 projects were financed with a total amount of 9 million euro.

In parallel to PRAXE, an action for the creation of Venture Capitalist was found by $50 \%$, through the New Economy Development Fund (TANEO) in accordance with Law 2992/2002, creating eleven VC companies (AKES,THERMI,IBG,ATTICA VENTURES,AXON,ALPHA VENTURES, OXYGEN NEOVENTURES, GIVE, PIRAEUS, NEW MELLON, TANEO FG RES FUND) a total new activity for the Greek financial system. Furthermore the Fund of Securities for Small and Micro Enterprises (TEMPME) was created to support loans for expansion plans and operations control.

Concluding, there are two main constraints concerning the policy framework influencing the spin-off creation within the West Macedonia region, which create a vicious cycle: 
a. The concentration of technological innovation powers within central government. The regions do not in fact have any formal powers in policy design. In other words, a policy framework influencing the spin-off creation formulated at regional level must be negotiated and agreed with the central government, which have the legislative authority and the budgetary means to implement it.

b. The lack of a regional institutional structure to administrate and control regional frameworks. Greece is divided to regions but these structures are simple deconcentrate administrative units supervised by the central government, with no executive powers. The role of the region of the West Macedonia is to act as an intermediary between the prefectures and local authorities and the central government in granting public funds, particularly European regional funds.

Such a structure cannot be a forum for defining a regional strategy to promote the spin-off creation at local level, or any other policy. The central authorities however, claiming the non-existence of an executive structure at regional level reclaim the control of regional related frameworks.

Regulations however for establishing new enterprises are complex and costly activities. Overall the regulatory framework for establishing and operating an enterprise in Greece and innovation related activities, is considered as one of the worst in European Union, ranking Greece to 7 I $^{\text {st }}$ place out of I33 at the Global Competitiveness Report (World Economic Forum, 2009).

The financing system supporting innovation and the spin-off creation in the region of West Macedonia can be described as relatively weak if an inter-regional comparison is made on a European level. However, in terms of the Greek banking and financial system, the region is undoubtedly no worse off than the other non- metropolitan areas. While both the public and the private banks, have competent engineers or economists in their personnel, the resources and autonomy of action, vis-à-vis their central headquarters, of the local branches would appear too limited to offer an effective service. Assisting companies to merge business development plans with innovation management and seed capital is beyond their remit and means. These banks in addition to providing business loans at relatively high rates, administer a number of government grant scheme for promoting development in the manufacturing and the services sector.
On the other hand the Hellenic Venture Capital \& Private Equity Association with its 18 members is very cautious to invest in the Greek periphery and only five companies reported contracts with the national venture capital system in 2009. This practically questions their role to support risk oriented ventures.

On the level of the Supportive Structures Framework, a number of technology transfer and business support organizations are operating in the region of West Macedonia such as:

- Centre of Entrepreneurship and Technological Development of West Macedonia (KETA).

- Management of Technology Research Lab (MaterLab) of the University of the West Macedonia.

- $\quad$ Centre of Technology Research (KTE) of the TEl of the West Macedonia

- The Hellenic Furs Centre.

- The development agencies of Kozani, Florina and Kastoria.

- The chambers of Commerce of Kozani, Florina, Kastoria and Grevena.

The operation of these centres forms a dynamic environment of technological infrastructure and steadily encourages the creation of spin-off companies. Also the orientation of these centres on creating sector specific clusters strengthens the competitive advantage of the region. On the other hand it is obvious that in most cases activities are limited to basic supportive services for immediate problem solving rather than technology and innovation oriented business development (Kyriafini and Sefertzi 200I). Most of these structures lack professional experience on entrepreneurial activity, long term operational horizon and strong and steady financial base.

At present, the major initiative which has been developed to respond to the acknowledged weaknesses of the regional innovation support infrastructure is the Technology Park of Ptolemais. The aims of this initiative are to promote the creation of new innovative enterprises and spin-offs as the seed for future employment in the region and to create new regional instruments, aimed at 
structural technology transfer to SMEs and the creation of new technology based firms. This initiative however unless it is supported strongly for several years (decades rather than years) and if not consolidate all the other structures under a common operational umbrella and strategy will be likely to prove fruitless.

All these observations are summarised at figure 6, showing that entrepreneurial activity and spin-off initiatives at West
Macedonia are destined to operate in a very unfriendly environment. All the supportive elements of our framework require significant improvement and political support in the long-term. Otherwise, good ideas and effort are diminishing and people will be de-motivated. This environment however, makes even more admirable the success of the STAR Fuel case but doesn't give us optimism for a sustainable spin-off creation process at West Macedonia.

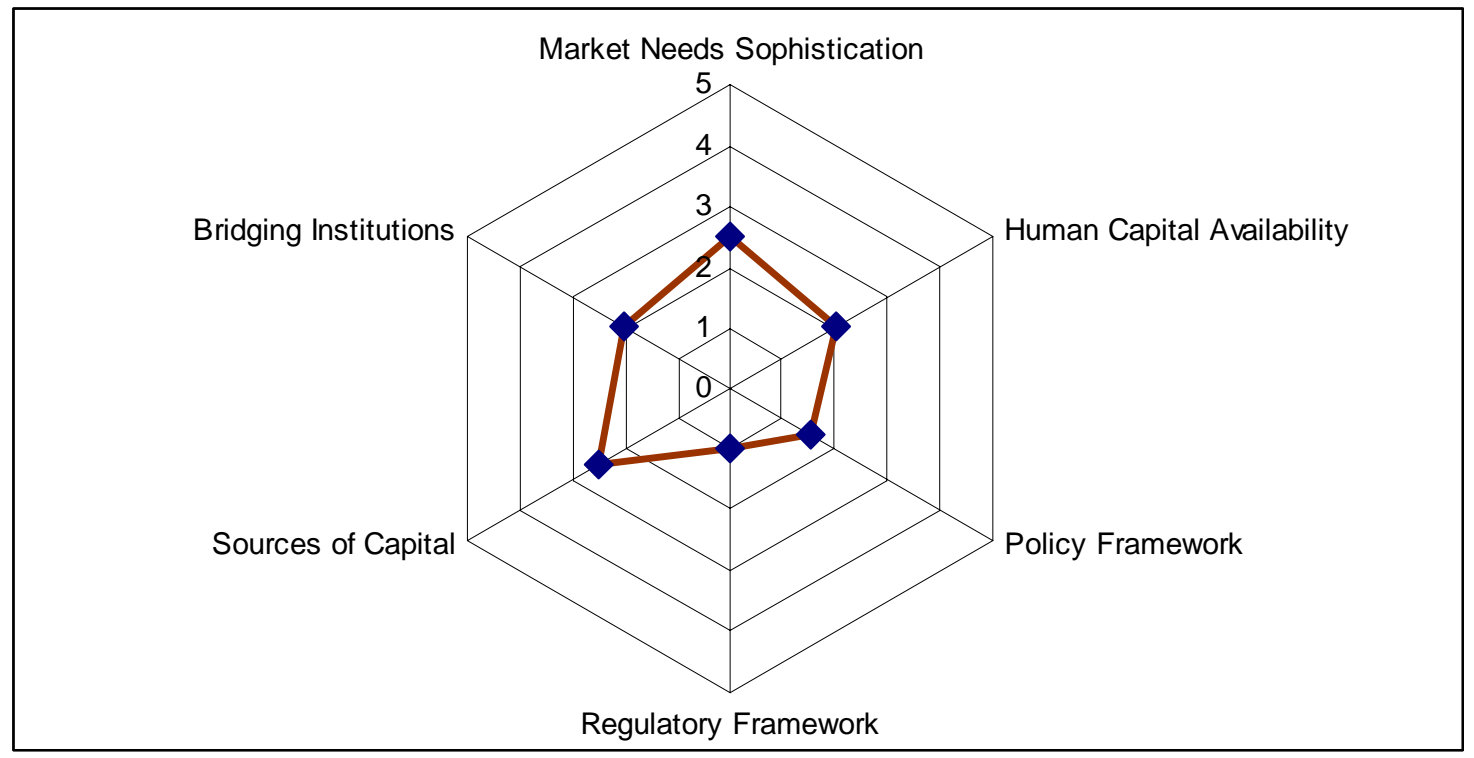

Figure 6. Supportive Structures and Environment Capacity of West Macedonia

\section{Conclusions}

Spin-off ventures are seen as a vehicle for transferring knowledge into application in society. Entrepreneurship, or more specifically the entrepreneurial action, is seen as the core process in the development of spin-off ventures. This paper addresses the process of a spin-off development in regions that have no such experience, by suggesting a new conceptual framework, the "Spin-off Chain". According to the framework the basic stages emerging as core to lead to entrepreneurial spin-offs are: the idea; the business concept; the financial sources; and, the entrepreneurial culture. These are influenced by the six components of the supportive structure and operational environment, namely: market needs; human capital availability; government policies; regulatory framework; sources of capital; and, bridging institutions.
The concept has used to analyse the spin-off generation capacity of the West Macedonia Region of Greece and raise awareness of the barriers and inconsistencies of the regional system. Following the Spin-Off Chain framework, the authors created a project that supported the development of the first spin-off company in the Region, originated to the newly established University of West Macedonia. So the purpose of this framework was twofold for the Region of West Macedonia. The first was to communicate and familiarise stakeholders with the process of spin-off development; and the second, to promote and support the broader exploitation of scientific and technological $R \& D$ results.

Implementing the concept in West Macedonia we demonstrated that it is possible to break the barriers to entrepreneurship that the general environment raises. Additionally, the project team managed to create in a pilot form a structured framework that raises awareness, 
activates the necessary institutions and create the appropriate networks. However, this pilot project does not replace a consistent effort by the regional stakeholders to build al the required conditions that the supportive structures and operational environment require for developing a sustainable spin-off generator for the region. Our experience is that without all the supportive elements in place the positive results will be scattered and faded immediately after the project finishes. Such incentives should be used by the regional stakeholders to 'buy time' in order to organise the structural elements of the framework and to use the initial results as examples convincing sceptical actors.

\section{References}

BATHELT, H., Kogler, D.F., Munro, A.K. (2010). A knowledge-based typology of university spin-offs in the context of regional economic development. Technovation. $30,519-532$.

BYGRAVE, W.D. (1989). The entrepreneurship Paradigm (I); A philosophical Look at its Research Methodologies, Entrepreneurship Theory and Practise. I4(I), I-26.

BIRD, B. (1988). Implementing Entrepreneurial Ideas; the Case for Intention. Academy of Management Review, I3, 442-453.

CARAYANNIS E., Rogers E., Kurihara K., Allbritton M. (1997). High Technology spin-offs from government R\&D laboratories and research universities. Technovation. I8(I), Pp. I-II.

CHIESA, V., Piccaluga, A. (2000). Exploitation and diffusion of public research: the case of academic spin-off companies in Italy. R\&D Management. 30(4), 329-339.

COHEN, W.F., Florida, R., Randazzese, L., Walsh, J. (1998). Industry and the academy: uneasy partners in the cause of the technological advance. In: Noll, R. (Ed.), Challenge to the Research University. Washington, DC, pp. 163-191.

COOPER, R.G. (1993). Winning at new products: accelerating the process from idea to launch. AddisonWesley. Reading, Mass.
DE COSTER, R., Butler, C. (2005). Assessment of proposals for new technology ventures in the UK: characteristics of university spin-off companies. Technovation, 25(5), 535-543.

DEGROOF, J.J., Roberts, E. (2004). Overcoming weak entrepreneurial Infrastructures for Academic Spin-off ventures. Journal of Technology Transfer. 29, 327-352.

DRUILHE, C., Garnsey, E. (200I). Academic spin-off ventures: a resource opportunity approach. In: W. During, R. Oakey and S. Kauser Eds., New technology-based firms in the new millennium. Pp. I75-190.

DRUIHE, C. Garnsey, E. (2002). Tracking the Emergence and Progress of University Spin-out Cases. IEEE International Engineering Management Conference. Cambridge.

ETZKOWITZ, H., Webster, A., Gebhardt, C., Terra, B.R.C. (2000). The future of the university and the University of the Future: evolution of ivory tower to entrepreneurial paradigm. Research Policy. 29(2), 3 I 3-330.

EUROPEAN COMMISSION (1998). Communication from the Commission to the Council and the European Parliament. Risk capital: a key to job creation in the European Union". Commission of the European Communities, Brussels.

EUROPEAN COMMISSION (2000). Communication from the Commission to the Council and the European Parliament. Progress report on the risk capital Action Plan (COM 2000) 658 final.

EUROPEAN COMMISSION (2003). Green Paper, Entrepreneurship in Europe. Document based on COM 27 final.

FRANKLIN, S., Wright, M., Lockett, A. (200I). Academic and surrogate entrepreneurs in university spin-out companies. Journal of Technology Transfer, 26, I27-|4I.

GARTNER, W.B. (1985). A Framework for Describing the Phenomenon of New Venture Creation. Academy of Management Review. 10, 696-706. 
GILSING, V.A., Elco van Burg, Romme, A.G.L, (20l0). Policy principles for the creation and success of corporate and academic spin-offs. Technovation. 30, 12-23.

GLADER, M. (2004). Innovation markets and competition analysis - EU competition law and US antitrust law. PP 2-4.

GOLDFARB, B., Henrekson, M. (2002). Bottom-up versus top-down policies towards the commercialization of university intellectual property. Research Policy. 32(4), 639658.

GOMPERS, P., Lerner, J. (1999). The Venture Capital Cycle.

GREENBERGER, D.B., Sexton, D.L (1988). An Interactive Model of New Venture Creation. Journal for Small Business Management. 26, I-7

KLOFSTEN M., Lindell P., Olofsson C.and Wahlbin C., (1988). Internal and External Resources in TechnologyBased Spin-off: A Survey. In: Kirchhoh B.A., Long W.A., McMullan E.W, Vesper K.H., Wetzel W.E. (Eds). Frontiers of Entrepreneurship Research. Babson College, 430-443.

LEE, Y.S, (1996). Technology transfer and the research university: A search for the boundaries of universityindustry collaboration. Research Policy. 25(6), 843-863.

LOCKETT, A., Wright, M. (2005). Resources, capabilities, risk capital and the creation of university spin-out companies. Research Policy. 34(7), 1043-1057.

LOWE, J. (1993). Commercialization of university research: a policy perspective. Technology Analysis and Strategic Management. 5(I), 27-37.

MINTZBERG, H. (1989). Mintzberg on Management: Inside our Strange World of Organizations. The Free Press, New York.

MOWERY, D.C., Shane, S. (2002). Introduction to the special issue on university entrepreneurship and technology transfer. Management Science. 48(I), v-ix.

MULLER, K. (2010). Academic spin-off's transfer speed Analyzing the time from leaning university to venture. Research Policy. 39, 189-199.
MUSTAR P., (1997). Spin-off enterprises. How French academics create high-tech companies: the conditions for success or failure. Science \& Public Policy. 24(I), 37-43.

MUSTAR, P., Renault, Colombo, M., Piva, M.G., Fontes, E., Lockett, M., Wright, A., Clarysse, M., and Moray, N. (2006). Conceptualizing the heterogeneity of researchbased spin-offs: a multi dimensional taxonomy. Research Policy. 35, 289-308.

NDONZUAU, F.N., Pirnay, F. and Surlemont B., (2002). A stage model of academic spin-off creation. Technovation. 22(5), 28I-289.

OAKEY, R. (1995). High-technology new firms: Variable barriers to growth. Paul Chapman, London.

OECD, (1999). Fostering entrepreneurship. OECD, Paris.

OECD, (2003). Turning science into business: patenting and licensing at public research organizations. OECD, Paris.

OWEN-SMITH, J., Riccaboni, M., Pammolli, F., Powell, W. W. (2002). A Comparison of U.S. and European University-Industry Relations in the Life Sciences. Management Science. 48(I), 24-43.

PEREZ, M.P., Sanchez, A.M., Martınez, A. (2003). The development of university spin-offs: early dynamics of technology transfer and networking. Technovation. 23, PP 823-83I.

PIRNAY, F., Surlemont, B., Nlemvo, F. (2003). Toward a typology of university spin-offs. Small Business Economics. 21, 355-369.

POWERS, J.B. and McDougall, P.P. (2000). University startup formation and technology licensing with firms that go public: a resource-based view of academic entrepreneurship. Journal of Business Venturing. 20(3), 291311 .

RADOSEVICH, R. (1995). A model for entrepreneurial spin-offs from public technology sources. International Journal of Technology Management. 10, 879-893.

RAPPERT, B., Webster, A., Charles, D. (1999). Making sense of diversity and reluctance: academic-industrial 
relations and intellectual property. Research Policy. 28(7), 873-890.

RASMUSSEN, E. (2006). Spin-off venture creation in a university context - An entrepreneurial process view. Bodo Graduate School of Business. Pp I-29.

RASMUSSEN, E., Borch, O.J. (2010). University capabilities in facilitating entrepreneurship: A longitudinal study of spin-off ventures at mid-range universities. Technovation, $39,602-612$.

RASMUSSEN, E., Moen, Ø., Gulbrandsen, M., (2006). Initiatives to promote commercialization of university knowledge. Technovation, 26, 518-533.

REITAN, B. (1997). Fostering technical entrepreneurship in research communities: granting scholarships to would be entrepreneurs. Technovation. 17(6), 287-296.

ROBERTS, E.B. (|99|). Entrepreneurs in High-technology: Lessons from MIT and beyond. New York, Oxford University Press.

ROBERTS, E.B. and Malone, D.E., (1996). Policies and structures for spinning off new companies from research and development organizations. R\&D Management. 26(I), 17-48.

ROGERS, E.M., Larsen, J.K. (1984). Silicon Valley Fever: Growth of high-Technology Culture, New York Editeur.

ROGERS, E.M. (1986). The role of the research university in the spin-off of high-technology companies. Technovation. $4,|69-| 8 \mid$

ROGERS, E.M. (1986). High tech companies that are University Spin-offs, Entrepreneurship and Technology. World experiences and policies. PP I34-I43.

ROWEN, H.S., (2000). Serendipity or Strategy: How Technology and Markets Came to Favor Silicon Valley. In: C.M. Lee, W.F. Miller, M.G.Hancock, and H.S. Rowen (eds). The Silicon Valley Hedge. A habitat for Innovation and Entrepreneurship. Stanford, CA: Stanford University Press. Pp. 184-199.

SAHLMAN, W. (1997). How to Write a Great Business Plan. Harvard Business Review.
SAMSON, K.J., Gurdon, M.A. (1993). University scientists as entrepreneurs: a special case of technology transfer and high-tech venturing. Technovation. 13(2), 63-7I.

SHANE, S. (2004). Academic entrepreneurship -University spin-offs and wealth creation. 353 pp. New horizons in entrepreneurship, edited by S. Venkataraman. Edward Elgar Publishing, Inc., Cheltenham.

STALK, G. Jr., Hout T.M. (1990). Competing against time: how time-based competition is reshaping global markets. Free Press.

STEVENSON H.H, Jarillo J.C. (1990). A Paradigm of Entrepreneurship: Entrepreneurial Management. Strategic Management Journal. Summer Special Issue, II, 17-27.

STOREY, D., Tether, B. (1998). Public policy measures to support new technology-based firms in the European Union. Research Policy. 26, 1037-1057.

TEMPLE L. (1996). European Community Antitrust Law: Innovation Markets and High Technology Industries. Fordham Corporate Law Institute. New York, p.4I.

VAN BURG, E., Romme, A.G.L., Gilsing, V.A., Reymen, I.M.M.J. (2008). Creating University Spin-Offs: A sciencebased design perspective. The Journal of Product Innovation Management. 25, II4-I 28.

WORLD ECONOMIC FORUM (2009). Global Competitiveness Report 2009-2010. Geneva, Switzerland.

WRIGHT, M., Birley, S., Mosey, S. (2004). Entrepreneurship and university technology transfer. Journal of Technology Transfer. 29, 235-246.

ZUCKER, L., Darby, M., Brewer, M. (1998). Intellectual human capital and the birth of US biotechnology enterprises. American Economic Review. 88(I), 290-306.

\section{About the Authors}

Samara Elpida (1980) graduated from the department of Mechanical Engineering, Aristotle University of Thessaloniki. She had her PhD with subject "Modelling National Innovation Systems. A perspective with System Dynamics", at the Department of Mechanical Engineers, University of West Macedonia. She collaborated with 
Thessaloniki Technology Park for the project "InnoPro". She has also participated in the organizing committee of the Eureka National Project Coordinators during the Greek Eureka Presidency. Until today she has participated as a researcher in many programmes at the University of West Macedonia. Her research interests include modelling of systems of innovation and of technological innovation, management of innovation and technology, and technology transfer.

Kostas Galanakis (1973) is Programme Leader of Executive Education at Nottingham Business School. His research between other focuses on Innovation, Entrepreneurship and Technology Management. He has a PhD in Engineering from Warwick University, Warwick Manufacturing Group, UK, in Modelling Innovation Systems using Systems Thinking Approach. Additional he has a MSc in Manufacturing Systems Engineering from Warwick Manufacturing Group and a BSc in Control Systems Engineering from the Technological Education Institute of Piraeus Greece.

Ass. Professor Yiannis L. Bakouros (1957) of "Technology Management" in the University of West Macedonia. He received his Ph.D. in management and administration, from Bradford University, UK. He was responsible for Thessaloniki Technology Park development. He also served as Chairman of Eureka National Project Coordinators during the Greek Eureka Presidency. Currently he is co-ordinator of the Initiative for Technological Cooperation with Balkans, advisor and head of Regional Innovation Strategy in Thessaly and member of the board of directors of Thessaly Technology Park. He served as project coordinator of RIS Thessaly, RIS+ Thessaly, Innovative Actions of Thessaly and EU partner coordinator of RIS South Central Bulgaria. He has been consulting various Regional Innovation Strategies and Innovative Actions across Greece and Europe.
Spyros Platias is an Engineer of Mines - Metallurgist NTUA and holder of postgraduate title on the study of "Metallurgical Manufacturing Processes and Management" from the University of Birmingham, U.K. He worked for many years in metallurgic and mining industries (Greek Ferroalloys HM, [Elbior] HM, [Mebior] HM, White Mining $\mathrm{HMs} \mathrm{Mr}$ a.) as well as in the [EBETAM] $\mathrm{HM}$ as person in charge of the department of Research Programs. He was also a person in charge for the foundation of the Technological Park in Thessaly in which he was the General Director until 2003. From March 2006 he teaches in the Department [Geo-technology] and Environment of Polytechnic Department in West Macedonia. Has participated in a number of National and European Programs, as the RIS, Invent, Innovation, RIS+, Innoregio, etc. He is a Reviewer of the program ULCOS (Ultra Low $\mathrm{CO} 2$ Steelmaking). 